\title{
Coral Stone Architecture, Chinese Porcelain, and Indian Ocean Artifacts along the Swahili Coast: Cross-Cultural Dynamics in Medieval East Africa \\ Vera-Simone Schulz
}

Kunsthistorisches Institut in Florenz - Max-Planck-Institut

\section{Abstract}

While the use of Chinese porcelain dishes in the stone towns along the Swahili coast has recently found much attention in art historical scholarship regarding the eighteenth to early twentieth centuries, the pre-history of these dynamics in the medieval period has up to now only been fully considered in other fields such as archaeology and anthropology. This paper sheds new light on the interrelations between the built environment and material culture in coastal East Africa from an art historical perspective, focusing on premodern Indian Ocean trajectories, the role of

Corresponding Author: Vera-Simone Schulz vera-simone.schulz@khi.fi.it

Received: 15 March 2019 Accepted: 25 May 2019 Published: 20 November 2019

Publishing services provided by Knowledge

(c) Vera-Simone Schulz. This article is distributed under the terms of the

Attribution License, which permits unrestricted use and redistribution provided that the original author and source are credited.

Selection and Peer-review unde the responsibility of the Architecture across Boundaries Conference Committee.

\section{G OPEN ACCESS}

Chinese porcelain bowls that were immured into Swahili coral stone buildings, and on architecture across boundaries in a medieval world characterized by far-reaching transcultural entanglements and connectivity. It will show how Chinese porcelain bowls in premodern Swahili architecture linked the stone towns along the coast with other sites both inland and across the Indian Ocean and beyond, and how these dynamics were shaped by complex intersections between short-distance and long-distance-relationships and negotiations between the local and the global along the Swahili coast and beyond.

Keywords: architecture across boundaries; Swahili coast; premodern Indian Ocean trajectories; material culture and the built environment; transcultural art history

\section{Introduction}

Porcelain dishes decorating the walls of merchant mansions in hundreds, arranged in intricate patterns [Fig. 1]: the impact of Chinese porcelain along the Swahili coast has recently found much attention in art historical scholarship regarding the time period from the eighteenth to the early twentieth century [1]. It has been studied in the context of the mobility of artifacts, issues of materiality, transcultural dynamics, and the notion of a Swahili 'identity' characterized by the impact of the maritime connections of this region, the appreciation and appropriation of imported objects, and their incorporation and display in the built environment [1]. This paper seeks to contribute to these discourses 
by shedding new light on the pre-history of these dynamics, focusing on the impact of imported ceramic and porcelain ware along the Swahili coast before 1500. While Chinese porcelain shards and dishes have been studied in coastal East Africa as chronological markers, i.e. as a means to date archaeological layers or buildings; as symbols of power of a Swahili elite; as decorative features when immured into buildings; and in the context of local practices of feasting in archaeology and anthropology [2], this paper will approach this topic from an art historical perspective. Investigating the interrelations between Chinese ceramic ware and the built environment along the Swahili coast within the context of transcultural trajectories in and beyond the premodern Indian Ocean, this paper will show how the incorporation of imported artifacts into Swahili monuments can in fact be addressed as architecture across boundaries, being part of a complex intersection of short-distance and long-distance relationships, and negotiations between the local and the global in the premodern world.

\section{Architecture Across Boundaries along the Premodern Swahili Coast}

\subsection{Rich Cities along the Shoreline}

Following the coast from Southern Somalia to Northern Mozambique and including adjacent islands such as the Lamu, Mafia, and Zanzibar archipelagoes, the Comoros and Northern Madagascar, the ruins of Swahili stone towns bear witness of the wealth of their inhabitants during - what in a Eurocentric terminology would be called - the middle ages and early modern period. Islam had arrived in this region already in the eighth century C.E. and by the twelfth century was spread widely along the coast [3], its presence being testified by the remains of numerous mosques [Fig. 2, 3], tombs, and mausolea [Fig. 4]. This evidence of premodern Islamic architecture, the high number of monuments built of stone, and local origin stories narrating the founding myths of Swahili cities by Persian princes in the tenth century led scholars to argue that the stone towns along the Swahili coast were indeed erected by Persians and Arabs, an argument which was particularly discussed during the colonial period, when the latter were thought of as 'pre-colonial colonizers' having brought 'civilization' to this part of Sub-Saharan Africa before the arrival of the Europeans [4]. While this theory has long been dismissed, the premodern cities along the shoreline are now considered to have developed as Swahili settlements over time, becoming rich through trading contacts with merchants from the Arabian Peninsula, Persia, the Indian subcontinent and other regions in and beyond 
the premodern Indian Ocean world, fostered by the navigation opportunities based on the monsoon winds [5]. Whereas the northeast monsoon allowed the navigation from India and the Persian Gulf to East Africa from November through March, shifting winds in April now in southwest direction enabled their return [6]. Swahili cities such as Mogadishu, Manda, Ungwana, Kilwa Kisiwani and Songo Mnara exported ivory, gold, rock crystal, copper, iron, ambergris, resins, rhinoceros horns, leopard furs, tortoise shells, and mangrove poles, while importing glass beads, bottles and beakers, copper bowls and jewelry, cotton cloths and silk weavings, ceramic dishes and porcelain from various parts of the Indian Ocean world and beyond [7]. More than only of importance to economic historians and archaeologists, these transcultural dynamics, however, also came to shape the aesthetics of premodern Swahili cities, giving rise to an architecture across boundaries in coastal East Africa.

\subsection{The Mobility of Artifacts}

While the mobility of artifacts has recently been much studied in the humanities, celebrating notions of connectivity, it is not least the challenges and the site-specific ways of coming to terms with and appropriating objects that allow new insights into transcultural dynamics in the premodern period. Scholars have thus recently elucidated the way how qingbai ware from China erupted taxonomies of Jewish law in medieval Aden when the inhabitants of this Indian Ocean port city did not know how to treat these objects in their households, when qingbai ware had newly arrived and become more and more frequent on the markets of the city. Based on textual evidence from the Cairo Geniza, historians of law and material culture could show how the Jewish community of medieval Aden wondered whether they could use qingbai artifacts characterized by a very translucent surface as they used other types of objects such as earthenware or glass [8]. Qingbai ware has also been unearthed in the stone towns along the Swahili coast [9]. Yet, here we do not have textual documents that we could analyze in order to understand the roles that these objects might have played in medieval coastal East Africa. We do, however, have evidence for the use of other ceramic artifacts from China along the premodern Swahili coast: celadon dishes and blue-and-white porcelain that were immured into walls and ceilings, both on the interior and the exterior of Swahili architecture, and that can be scrutinized regarding transcultural entanglements and intersections between the local and the global in the premodern world. 
In architectural history, transcultural dynamics between the built environments of diverse regions are mostly studied regarding the mobility of architects, the transportation of raw materials, the transmission of building techniques, architectural 'styles', or that of building elements, in the context of the premodern period particularly that of spolia, i.e. re-used building materials such as columns, often involving diverse temporal layers (such as in the case of the re-use of antique works of architecture in later periods) or trophies (such as in the case of the appropriation of building elements from the monuments of conquered enemies). To these, one can add the role of mercantile dynamics at play in the creation of architectural complexes, not least in a transcultural perspective. In the case of the premodern Indian Ocean world, one such example would be the high prestige and wide dissemination of marble carvings from Cambay in Gujarat in Western India, particularly from the thirteenth- to fifteenth-century, when marble tombstones and architectural elements from Gujarat were shipped to regions from Oman on the Arabian Peninsula to Java and Sumatra in South-East Asia. As Elizabeth Lambourn has discussed, coastal East Africa was part of these far-reaching Indian Ocean networks, as can be seen from a medieval Gujarati tombstone that was unearthed at Kilwa Kisiwani [Fig. 5], and from the pieces of a marble mihrab (i.e. prayer niche) from Gujarat preserved in the Fakhr al-Din Mosque in Mogadishu [10]. But the question arises, whether also the intersections of architecture and artifacts can provide insights in this context, not least regarding the renewed scholarly interest in architectural ornament between the local and the global in the premodern world [11].

\subsection{Short-Distance and Long-Distance Relationships, Intersections between the Local and the Global}

The premodern buildings featuring immured ceramic and porcelain dishes along the Swahili coast can be approached from a site-, even monument-specific perspective: when local artists found ever new ways to incorporate imported artifacts into architectural structures, sometimes in one and the same monument. In the case of the early fifteenth-century, so-called Small Mosque at Kilwa Kisiwani, Persian ceramic bowls can be seen radiating around the apex in one dome [Fig. 3], while another, now fluted dome of the same building features only one ceramic dish at the top, the flutes recalling a folded canopy, hanging from a jewel-like bowl [12]. Premodern Swahili architecture with immured ceramic and porcelain dishes can be studied regarding the interplay of different aesthetic choices in diverse monuments in the same city or regarding those between cities: when we encounter similarities and differences, 
for example, between Ungwana and Kilwa Kisiwani in the fourteenth and fifteenth centuries [12]. They raise questions about dynamics over time: when Persian ceramic dishes were the first imported artifacts to be immured into Swahili monuments, which were then replaced by intricate assemblages of Persian ceramic dishes together with Chinese ceramic ware, i.e. objects from diverse geographical regions, before being more and more outnumbered and finally completely substituted by Chinese celadon and particularly blue-and-white porcelain dishes in the fifteenth and sixteenth centuries. And they concern issues of materiality, not least in a transcultural, transmedial, and even transmaterial perspective: when Swahili monuments dotted with imported ceramic and porcelain dishes resembling giant polychrome beads or pearls were characterized by vibrant surfaces that put various (present or evoked) media and materials into dialogue.

Swahili monuments featuring imported ceramic and porcelain dishes can thus be described as "architecture across boundaries" in various ways: on the one hand, in a media and materials transgressing perspective, questioning the common way of studying architecture and objects of material culture separately from one another; and, on the other hand, in the context of the complex entanglements and intersections between the local and the global - including their various gradations - in the premodern world. The latter, however, did not only concern interrelations between artifacts imported from various

parts of the Indian Ocean world as far as China and local Swahili architecture, but also the artistic practices themselves of immuring ceramic and porcelain dishes into architectural structures. In the premodern period, such practices were in fact widespread, with early examples known from the medieval Mediterranean, where ceramic bowls from Fatimid Egypt, Mallorca, and Al-Andalus were immured into church facades in Pisa [Fig. 7] and elsewhere on the Apennine peninsula and across the Mediterranean basin $[12,13]$. The earliest extant example known from Oman, where Chinese blue-andwhite porcelain bowls came to be immured into numerous prayer niches of mosques [14], dates only from 1504 C.E. [Fig. 8], but practices of incorporating ceramic bowls into facades, walls and ceilings from thirteenth- and fourteenth-century Yemen are also known [15]. And it was in fact the Indian Ocean world, where immured ceramic and soon particularly Chinese porcelain dishes became one of the most widespread architectonic feature connecting regions as distant as coastal East Africa, the Arabian Peninsula and Persian Gulf all the way to Indonesia [Fig. 9], Thailand and Vietnam in South-East Asia [16].

In the discipline of art history, monuments from these regions are traditionally studied in diverse art historical sub-disciplines such as Italian, Islamic, Byzantine, Indian Ocean, 
African, and (South, East and South-East) Asian art history and archaeology. Yet, the wide dissemination of the incorporation of ceramic and porcelain dishes into built structures and the crucial role of transcultural networks and connectivity in the premodern Indian Ocean world and beyond through trade, pilgrimage, and other dynamics call in fact for transdisciplinary dialogue and collaboration in order to investigate both the sitespecificity of the appropriation of imported ceramic and porcelain dishes in the built environment in different locations and their entanglements and connections across time and space.

In the case of the Swahili coast, these issues can in fact be approached on micro-, meso-, and macro-levels. Important research has already been presented from archaeology and anthropology concerning different sites that can be enhanced by art historical studies regarding the aesthetics of premodern Swahili port cities characterized by the impact of imported ceramic and porcelain bowls immured into architectural complexes and monuments. These dynamics need to be considered in the longue durée, both regarding the way how by the late nineteenth century, Swahili merchants let themselves be photographed in front of walls studded with porcelain bowls in their mansions, and in the context of cultural heritage and conservation issues, when many of the cavities once bearing immured ceramic and porcelain dishes are now empty due to the looting of ancient Swahili monuments [Fig. 4]. But they also need further studies regarding transcultural dynamics and processes of artistic transfer during the premodern period itself.

In premodern Swahili stone towns, the aesthetics of the built environment were in fact characterized by intricate intersections between the local and the global in various ways. When Chinese celadon and porcelain dishes were incorporated into architectural structures in coastal East Africa, they were immured into architecture built of coral stone that was harvested from the sea nearby and thus a specifically local material. In a region that did not have any marble quarries nor any other types of stone locally available, coral constituted the only building material for stone architecture except for the rare marble artifacts imported to the Swahili coast from Gujarat in Western India such as the tombstone at Kilwa Kisiwani and the pieces of the mihrab preserved in Mogadishu. But while Swahili monuments are today darkened through the passing of time, hence making the difference between local coral stone from coastal East Africa and the creamy white marble from Western India clearly apparent, Swahili coral stone monuments were actually much lighter in color when they were newly built, since coral stone [Fig. 6], when freshly harvested, has an almost marble-like finish. Rather than being a material 
of lower quality, coral stone architecture was thus in fact well-prepared to compete with the luxury marble

carvings from afar by its own materiality and even more when studded with jewel- or pearl-like ceramic and porcelain ware, creating multiple visual dialogues across media and materials.

The multi-layered buildings along the premodern Swahili coast characterized by immured ceramic and porcelain dishes thus call for case studies from monument to monument and from site to site rather than for generalizations. They call for new attempts to transgress sub-disciplinary boundaries by studying them together with related practices of immuring ceramic and porcelain bowls in the wider Indian Ocean world and beyond, but they also call for new pluri-directional approaches [Fig. 10]. Since as significant as the maritime connections of coastal East Africa were and as much as Swahili stone towns were directed towards the sea, there were also multiple dynamics towards locations inland. Imported artifacts from various regions in and beyond the Indian Ocean world that came to be immured into Swahili monuments were in fact also traded from city to city along the Swahili coast as well as to kingdoms inland. Objects from various regions excavated in Zambia, Great Zimbabwe, Northern South Africa and elsewhere in Sub-Saharan Africa including the Yuan or early Ming Chinese celadon dishes unearthed on Mapungubwe Hill [Fig. 13] had arrived there in fact through interactions with Swahili merchants from the coast already in the premodern period [17]. By incorporating and proudly displaying imported artifacts in their monuments such as in the case of the large Chinese celadon dish that once graced the upper main cavity of a fourteenth- or early fifteenth-century prestige tomb in Ungwana, Kenya [Fig. 11, 12], Swahili artists thus did not only create complex intersections of architecture, objects, and ornamentation, but they also gave visual emphasis to objects that had crucial roles on micro-

, meso-, and macro-levels in a pluri-directional manner: from the site-specific local contexts - the community of Ungwana and the prestige role that the deceased played in this very community -, to a transregional context of short-distance relationships - both along the Swahili coast, for instance, regarding artistic dynamics between Ungwana and Kilwa Kisiwani, and those between the Swahili coast and regions much further inland -, to the macro-context of transcultural dynamics, Indian Ocean trajectories, and architecture across boundaries in the wider Indian Ocean world and beyond. 


\section{Conclusion}

While Europe has long been privileged in scholarship regarding receptions of and responses to Chinese porcelain in the premodern world, recent studies have more and more elucidated the crucial impact of Chinese ceramic ware in other parts of the globe $[1,18]$. This paper has shed new light on the role of Chinese celadon and blue-and white porcelain dishes in the built environment in coastal East Africa before 1500 from an art historical perspective, addressing notions of connectivity, transcultural entanglements, and complex intersections between long-distance and short-distance relationships, the site-specific and the global. Long marginalized in art history, even within the discipline of Islamic art history, this paper has shown that the built environment along the premodern Swahili coast does indeed deserve further studies and investigation, now that the field of art history is opening up to a global horizon. It has dicussed the impact of imported artifacts both from a monument- and site-specific, as well as from further transregional and even global perspectives, and it has shown that the incorporation of Chinese celadon and blue-and-white porcelain dishes into Swahili monuments is a case in point regarding architecture across boundaries, animating and urging us to think about ages of premodern globalization.

\section{Conflict of Interest}

The author has no conflict of interest to declare.

\section{Figures}

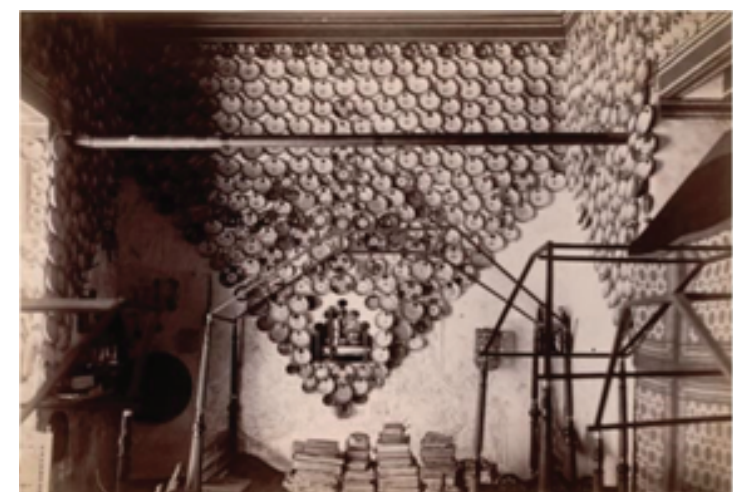

Figure 1: Sir John Kirk, Interior of an $18^{\text {th }}$-cent. merchant house in Lamu Town, Kenya, 1884. Edinburgh, National Library of Scotland. 


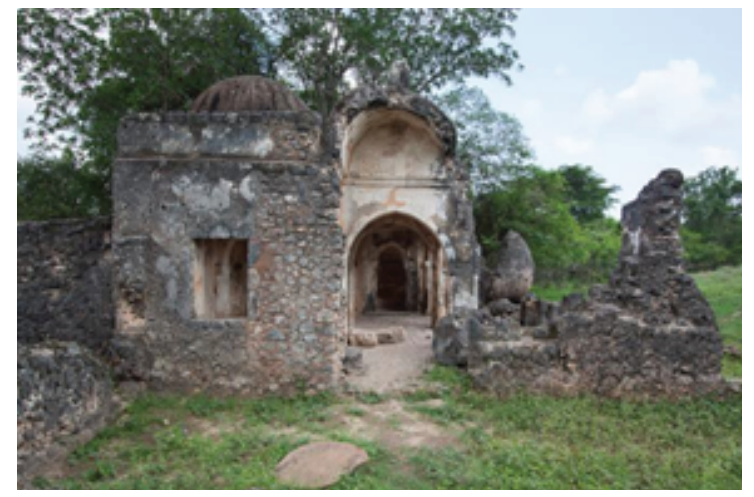

Figure 2: Small Mosque, $15^{\text {th }}$ cent., Kilwa Kisiwani, Tanzania.

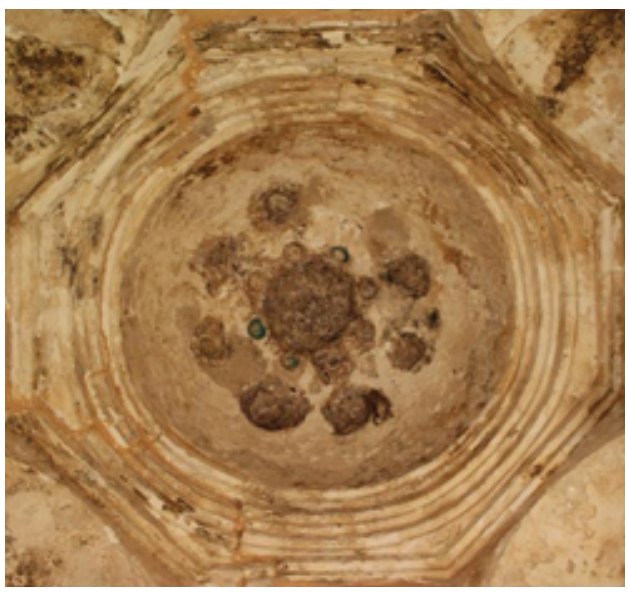

Figure 3: Imported ceramic bowls immured into one of the domes of the Small Mosque, Kilwa Kisiwani.

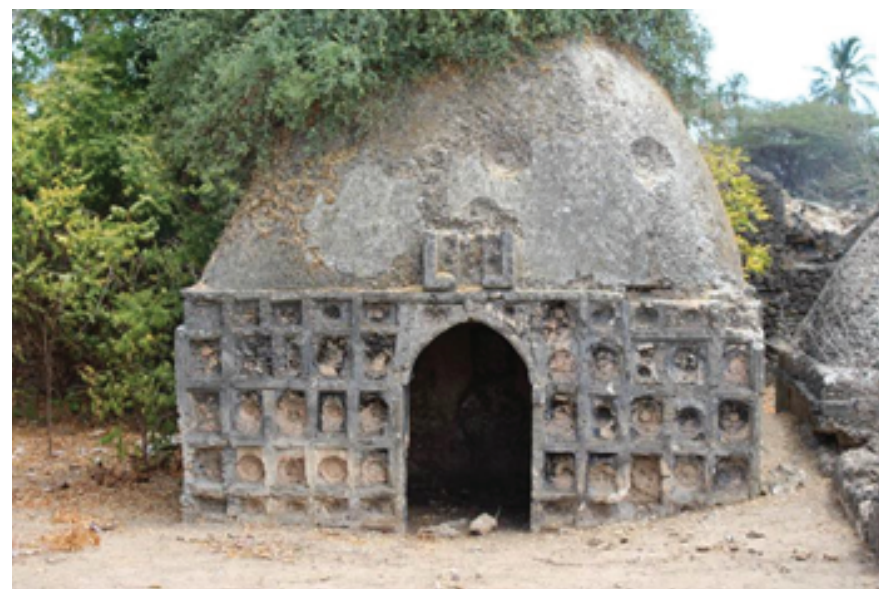

Figure 4: Mausoleum at Siyu on Pate Island, Lamu Archipelago, Kenya. 


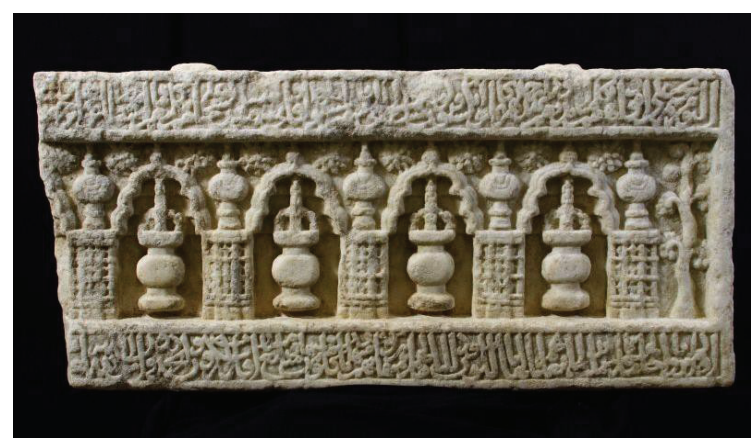

Figure 5: Marble tombstone from Gujarat, India, excavated at Kilwa Kisiwani, Tanzania, Berlin, Ethnological Museum.

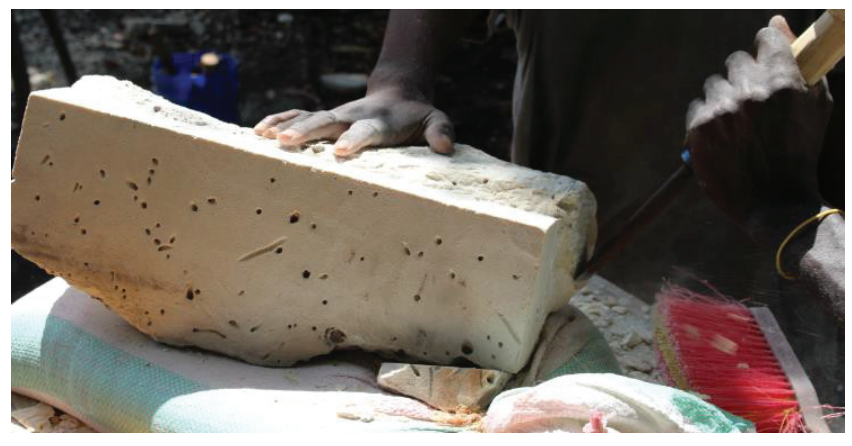

Figure 6: Fresh coral stone worked for a restoration project in Tanzania.

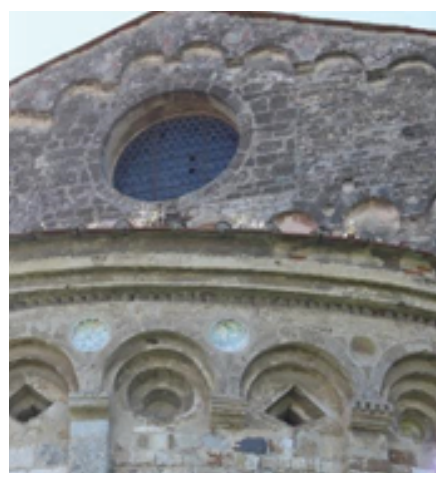

Figure 7: Imported ceramic bowls immured into the church of San Piero a Grado, Pisa, Italy.

\section{References}

[1] Meier, P. (2015). Chinese porcelain and Muslim port cities: Mercantile materiality in coastal East Africa. Art History, vol. 38.4, 2015, pp. 702-717; Meier, P. (2009). Objects on the edge: Swahili coast logics of display. African Arts, pp. 8-23; Meier,

P. (2016). Swahili Port Cities: The Architecture of Elsewhere, Bloomington: Indiana University Press. See also Meier, P. and Purpura, A. eds. (2018). World on the Horizon: 


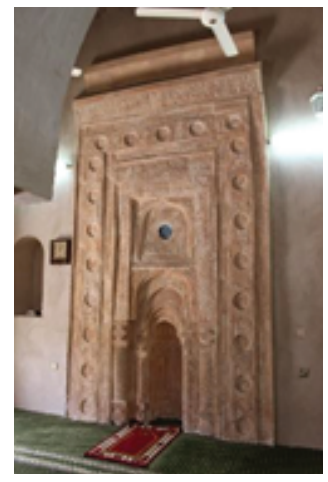

Figure 8: Porcelain bowl immured into the prayer niche of Al-Ayn, Oman.

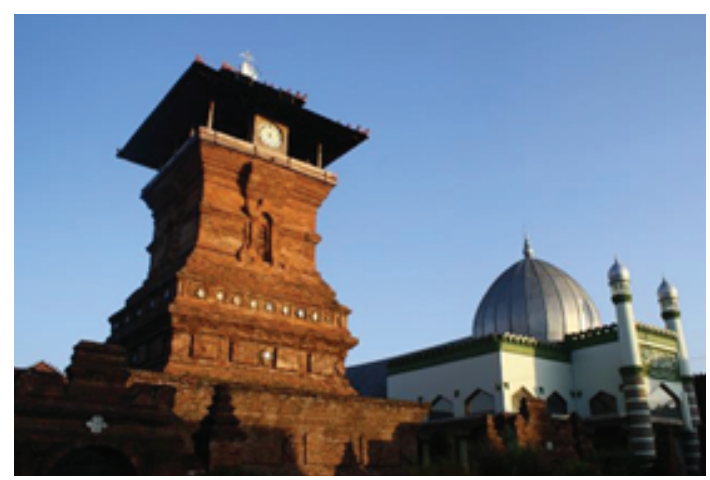

Figure 9: Porcelain bowls immured into the minaret of the Menara Kudus Mosque, Kudus, Java, Indonesia.

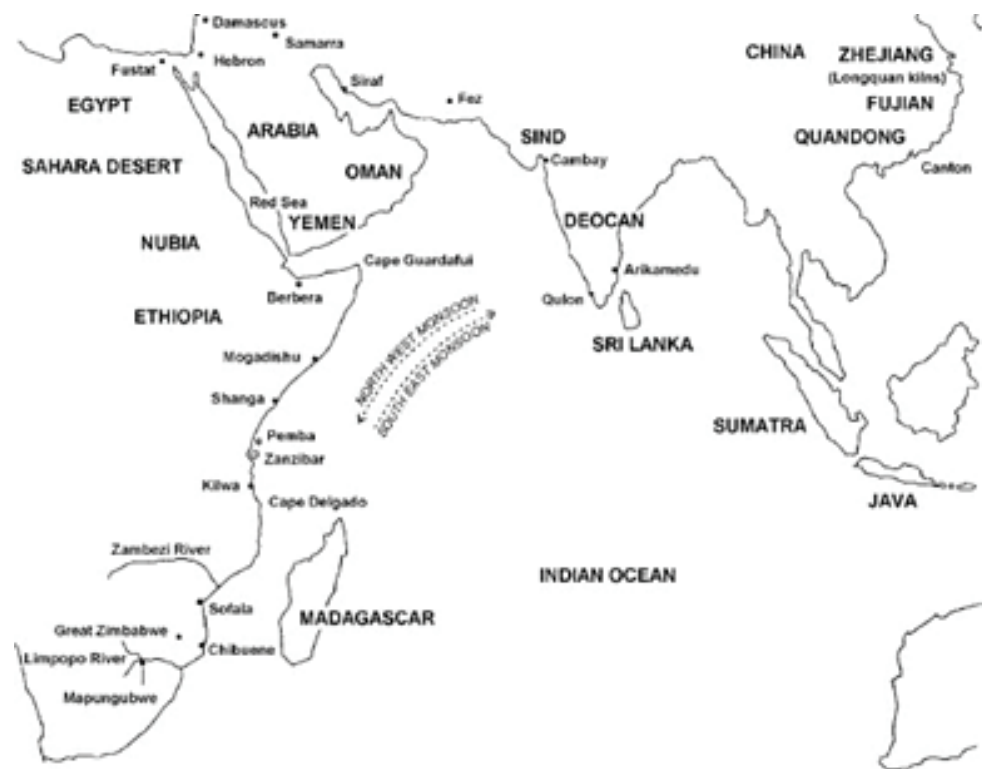

Figure 10: Map of the East African coast and the wider Indian Ocean world (Prinsloo et al. 2005).

Swahili Arts Across the Indian Ocean, exhibition catalogue (Krannert Art Museum and Kinkead Pavillion). Seattle: University of Washington Press.

[2] Zhao, B. (2013). Luxury and Power: The Fascination with Chinese Ceramics in Medieval Swahili Culture. Orientations: The Magazine for Collectors and 


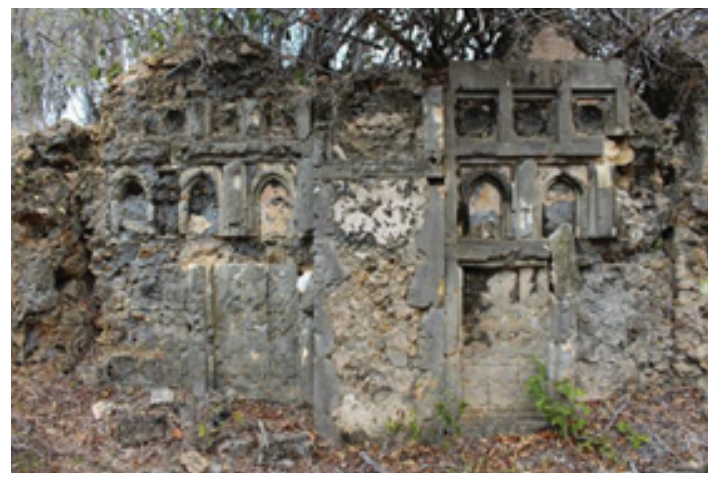

Figure 11: 14th- or early 15th-cent. tomb with cavities Once holding immured celadon and blue-and- white porcelain bowls, Ungwana, Kenya.

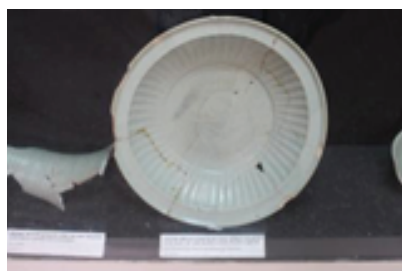

Figure 12: Chinese celadon bowl, 14th cent., excavated at Ungwana, National Museum, Lamu Town, Kenya.

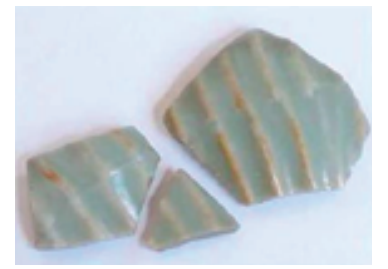

Figure 13: Chinese celadon potshards, Yuan or early Ming, Mapungubwe hill, South Africa.

Connoisseurs of Asian Art, vol. 4.3, pp. 71-78; Zhao, B. (2012). Global trade and Swahili cosmopolitan material culture: Chinese-style ceramic shards from Sanje ya Kati and Songo Mnara (Kilwa, Tanzania). Journal of World History, vol. 23.1, pp. 41 85; Wynne-Jones, S. (2016). A Material Culture: Consumption and Materiality on the Coast of Precolonial East Africa. Oxford: Oxford University Press, p. 44; Montella, A. (2016). Chinese porcelain as a symbol of power on the East African coast from the 14th century onward. Some reflections on the funerary context. Ming Qing Yanjiu, vol. 20.1, pp. 74-93; Fleisher, J. (2010). Rituals of consumption and the politics of feasting on the East African coast, AD 700-1500. Journal of World Prehistory, vol. 23, pp. 195-217.

[3] Horton, M. (1991). Primitive Islam and architecture in East Africa. Muqarnas, vol. 8, pp. 103-116; Insoll, T. (2003). The Archaeology of Islam in Sub-Saharan Africa. Cambridge: Cambridge University Press. 
[4] See, for example, Kirkman, J. (1954). The Arab City of Gedi. Oxford: Oxford University Press.

[5] For an overview of historiographical debates and new research, see Horton, $M$. and Chami, F. (2018). Swahili Origins, in The Swahili World, ed. S. Wynne-Jones and A. LaViolette, London/New York: Routledge, pp. 135-146.

[6] Hoyle, B.S. (1967). Early port development in East Africa. Tijdschrift voor Economische en Sociale Geograpfie, vol. 58, pp. 94-106.

[7] Whitehouse, D. (2001). East Africa and the maritime trade of the Indian Ocean, AD 800-1500, in Is/am in East Africa: New Sources, ed. B.S. Amoretti, Rome: Herder, pp. $411-424$.

[8] Lambourn, E. and Ackerman-Lieberman, Ph. (2016). Chinese porcelain and the material taxonomies of medieval Rabbinic law: Encounters with disruptive substances in twelfth-century Yemen. Medieval Globe, vol. 2.2, article 9.

[9] Zhao, B. (2015). Chinese-style ceramics in East Africa from the 9th to 16th century: A case of changing value and symbols in the multi-partner global trade. Afriques, vol. 6.

[10] Lambourn, E. (2003). La production de marbre sculpté à Cambaye au Gujarat et son exportation dans I'Océan Indien (XIIle-XVe s. ap. J.C.), in Mirabilia Asiatica: Produtos raros no comércio marítimo, ed. J.M. Santos Alves, C. Guillot and R. Ptak, Wiesbaden/Lisbon: Harrasowitz, vol. 1, pp. 209-252; Lambourn, E. (1999). The decoration of the Fakhr-al-Din Mosque in Mogadishu and other pieces of Gujarati marble carving on the East African coast. Azania, vol. 34, pp. 61-86.

[11] Necipoğlu, G. and Payne, A. (2016). Histories of Ornament: From Global to Local. Princeton/Oxford: Oxford University Press.

[12] Schulz, V.-S. (2018). Artistic dynamics across the seas: Architecture, objects, and ornamentation in the medieval port cities Kilwa, Songo Mnara and Pisa, in Early Maritime Cultures in East Africa and the Western Indian Ocean, ed. A. Sarathi, Oxford: Access Archaeology, pp. 185-214.

[13] Berti, G. and Tongiorgi, L. (1981). I bacini ceramici medievali delle chiese di Pisa, Rome: L'Erma di Bretschneider; Mathews, K.R. (2014). Other people's dishes: Islamic bacini on eleventh-century churches in Pisa. Gesta, vol. 53, pp. 5-23; Abulafia, D. (1985). The Pisan 'bacini' and the medieval Mediterranean economy: A historian's viewpoint. Papers in Italian Archaeology IV: The Cambridge Conference. British Archaeological Reports, International Series, vol. 245, pp. 287-296. 
[14] Bandyopadhyay, S. (2008). From another world! A possible Būyid origin of the decorated mihrāb of Central Oman? BAR International Series, vol. 1826, pp. 372382; Goffriller, M., Hongjiao, M., Bandyaopadhyay, S. and Henderson, J. (2015). Chinese porcelains and the decoration of Omani mihrabs. Proceedings of the Seminar for Arabian Studies, vol. 45, pp. 1-16.

[15] Ventrone Vassallo, G. (1996). Decorazione con inserti di ceramica nell'architettura islamico dello Yemen, in Atti XXVI convegno internazionale della ceramica: I bacini murati medievali. Problemi e stato della ricerca, pp. 329-345.

[16] Tajudeen, I. (2013). Java's architectural enigma: The Austronesian world and the limits of 'Asia', in Architecturalized Asia: Mapping a Continent through History, ed. V. Rujivacharakul, H. Hahn, K. Tadashi Oshima and P. Christensen Honolulu: University of Hawai'i Press, pp. 221-258; Sukkham, A. (2015). Ceramic decorations on Buddhist temples in Surat Thani and Nakhon Si Thammarat, Thailand, in Maritime Contacts of the Past: Deciphering Connections amongst Communities, ed. S. Tripati. New Delhi: Delta Book World, pp. 275-299.

[17] Prinsloo, L., Wood, N., Loubser, M., Verryn, S. and Tiley, S. (2005). Re-dating of Chinese celadon shards excavated on Mapungubwe Hill, a 13th century iron age site in South Africa, using Raman spectroscopy, XRF and XRD. Journal of Raman Spectroscopy, vol. 36, pp. 806-816.

[18] Priyadarshini, M. (2018). Chinese Porcelain in Colonial Mexico. The Material Worlds of an Early Modern Trade. Cham: Palgrave MacMillan. 